\title{
PROBLEMS OF PRESERVATION AT THE NEOLITHIC LAKESIDE SETTLEMENTS AT LAKE BURGÄSCHI, SWITZERLAND. A CASE STUDY ON THE EFFECTS OF AN ARTIFICIAL LOWERING OF THE LAKE LEVEL IN 1943
}

\author{
MARCO HOSTETTLER ${ }^{1}$, ALBERT HAFNER ${ }^{2}$
}

\begin{abstract}
This paper describes recently observed severe preservation problems at the Neolithic lakeside settlement of Aeschi SO, Burgäschisee, Nord. The site is located on Lake Burgäschi, a small water body of late-glacial origin in Central Switzerland. Since an artificial lake lowering in 1943 and draining of the site, the originally waterlogged sediments have been increasingly drying out. Recent fieldwork on the site (2015-17) and its evaluation gave the opportunity to directly assess the actual preservation status of the archaeological site. The excavations show that the archaeological remains are affected by mechanical destruction caused by draining cracks and fissures and tree-uprooting, which have mixed parts of the stratigraphic sequences. Additionally, the organic matter is heavily deteriorated and most organic artefacts and environmental data are lost forever. The comparison of the newly obtained observations with older excavation data and neighbouring sites confirms a high loss of archaeological information. Even though there exist examples for successful rewetting and in-situ conservation of archaeological wetland sites, for the site of Aeschi SO, Burgäschisee, Nord the most reasonable measure to undertake seems to be a rescue excavation.
\end{abstract}

Key words: in-situ preservation, drainage of wetlands, organic deterioration, tree windthrow, wetland archaeology, Beyond Lake Villages

\section{Introduction}

The small Lake Burgäschi in Central Switzerland (Fig. 1) is among the first "pile-dwelling" sites to have been already excavated in the nineteenth century (Keiser 1879a, b). To date, five different Neolithic settlement sites and more than seven occupation phases are known around the lake, the oldest ascribed to the late $6^{\text {th }}$ millennium $\mathrm{BC}$, the youngest attributed to the Corded Ware Culture of the $3^{\text {rd }}$ millennium BC (Hafner, Hostettler in prep.).

The lake has a surface area of 21 ha, with a maximum water depth of $31 \mathrm{~m}$. The regulated water-level of Lake Burgäschi lies at $464.75 \mathrm{~m}$ a.s.1. (Zeh 2007). It has a hydrological catchment area of about $3.2 \mathrm{~km}^{2}$ (Guthruf et al. 1999). The lake level was lowered by more than $2 \mathrm{~m}$ in 1943 in order to drain the surrounding peat bog and transform it into agricultural land. A profound change in the ecosystem showed its full effects in the 1970s and 1980s when the lake suffered from severe eutrophication (Guthruf et al. 1999). The drainage led to the discovery of three Neolithic settlement sites, which were excavated soon after (Seeberg BE, Burgäschisee Südwest and Aeschi SO, Burgäschisee, Ost in 1945 and 1956, and Seeberg BE, Burgäschisee, Süd in 1957-58).

From 2015 to 2017 research was undertaken at lake Burgäschi within the framework of the international and interdisciplinary Project "Beyond Lake Villages: Studying Neolithic environmental changes and human impact at small lakes in Switzerland, Germany and Austria", funded by the Swiss National Science Foundation (SNSF), the German Research Foundation (DFG) and the Austrian Science Fund (FWF). The project aimed at evaluating human impact and ecological change at small lakes by combining palynological and archaeological research (Ebersbach et al. 2016; Rey et al. 2017; Hafner et al. 2020; Mainberger et al. 2020; Kowarik et al. 2020). Concerning archaeology, drillings, diving surveys, test excavations

\footnotetext{
${ }^{1}$ University of Bern, Institute of Archaeological Sciences and Oeschger Centre for Climate Change Research; Mittelstrasse 43, CH-3012 Bern, Switzerland; e-mail: marco.hostettler@iaw.unibe.ch, ORCID: 0000-0001-6981-4457

${ }^{2}$ University of Bern, Institute of Archaeological Sciences and Oeschger Centre for Climate Change Research (OCCR); Mittelstrasse 43, CH-3012 Bern, Switzerland; e-mail: albert.hafner@iaw.unibe.ch, ORCID: 0000-0003-2159-8569
} 
and re-evaluation of documents from previous excavations yielded new data on the already excavated sites and led to the discovery of at least two formerly unknown occupation phases at the lake (Hafner, Hostettler in prep.). Unexpectedly, it was possible to locate still-preserved areas of the site at Aeschi SO, Burgäschisee, Nord, which had been thought to have already been completely destroyed by the former excavations. Thus, a focal point of the research was placed on the northern shore, where between 2015 and 2017 about 10 test excavations were performed (Fig. 2). This allowed for new insights into the history of the settlement and for clarification of the chronology of its occupations (Hafner, Hostettler in prep.).

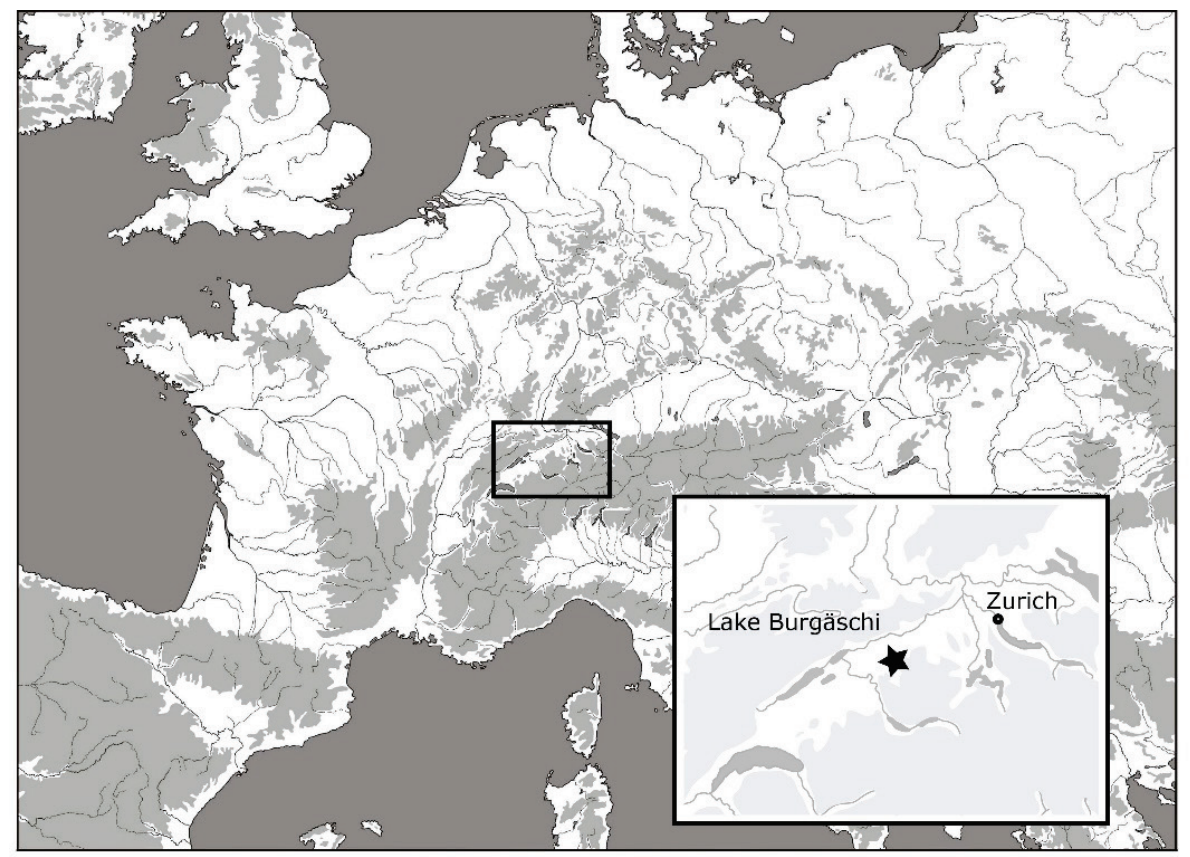

Fig. 1. Location of Lake Burgäschi

in Central Switzerland (star), on the border between the cantons of Bern and Solothurn

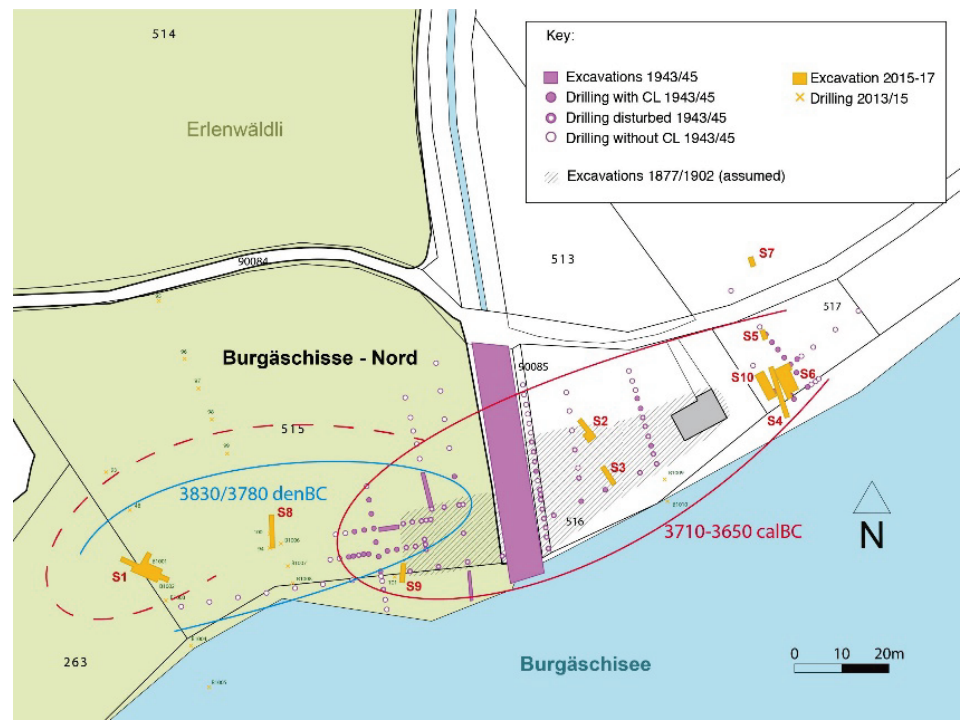

Fig. 2. Aeschi SO, Burgäschisee, Nord. Northern shore of Lake Burgäschi with locations of old excavations, drillings and trenches opened $2015-17$ by the Institute for Archaeological Sciences, University of Bern

S1-S10 (red) - trench numbers, CL - cultural layer

base map: Courtesy of the Canton of Solothurn, Modifications: M. Hostettler, Institute of Archaeological Sciences, University of Bern 
The excavations focused on the recovering of archaeological material and on the sampling of wooden piles for dendrochronology. However, the preservation of the site appeared to be in an alarmingly bad state. The organic layers have, in the meantime, deteriorated heavily, and the wooden piles could only be sampled deep in the ground below the permanent water table. Compared to the former accounts of the site, the excavated material was not even close to being as rich as it had been then.

The aim of this paper is to describe the observed problems of preservation at the site and to systematically assess the loss of archaeological information that has occurred in recent years. Subsequently, possible future strategies as in-situ preservation or rescue excavation of the site will be discussed.

\section{Preservation and state at Aeschi SO, Burgäschisee, Nord}

Although a considerable part of the site Aeschi SO, Burgäschisee, Nord on the northern shore of the lake was excavated in two campaigns in 1877 and 1902 and a new outflow was dug through the centre of the site in 1943 (when the lake level was artificially lowered), parts of the Neolithic settlement structures remained intact. Drillings from 1945 still showed the existence of preserved archaeological layers outside the already excavated zones. For unknown reasons, the preserved areas were forgotten, and remained undisturbed by human intervention for decades.
However, the archaeological object was not preserved in-situ but suffered severely from advancing deterioration. During the excavations of the years 2015-17, several serious instances of damage to the integrity of the site were documented and will be described in the following.

\section{A tree windthrow in a trench}

Trench \#1 was opened along an already existing crack in the ground. The main reason to open the test excavation along a feature of disturbed soil was to rescue the archaeological remains. The soil had been ripped by an uprooted tree. The tree-fall had happened several years before, as the appearance of the tree stump suggested. The trench was first opened to a length of about $6 \mathrm{~m}$ and later extended to $12 \mathrm{~m}$.

Figure 3 shows the documented stratigraphy in trench \#1. The trench cuts through the former root pit. The original stratigraphy can be reconstructed by comparison with the profile from metre 6-9, which was not too much affected by the uprooting. It is possible to distinguish a basic stratigraphy showing the lake marl and other "natural" sediments as the organic layer 5.5. On top of these layers the anthropogenic layers, 5.4-5.2 and $3-1$, are situated. They are a succession of organic detritus and mineral clay layers and represent at least three different occupation phases. Two different assemblages can be distinguished through the cultural differences in the material (the older consisting of layers 5.4-5.2 and the younger of the layers 3-1).

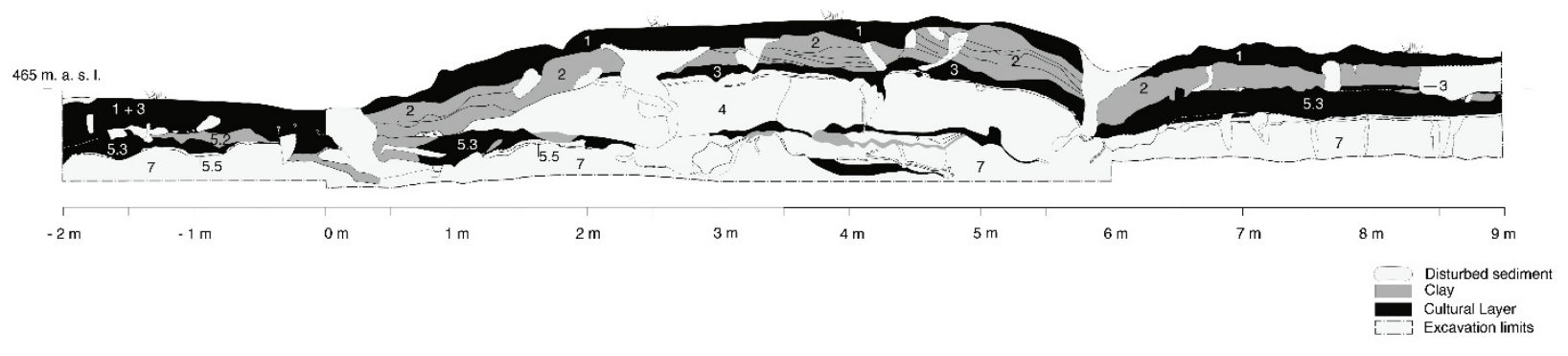

Fig. 3. Aeschi SO, Burgäschisee, Nord. Stratigraphy of trench \#1 seen on profile 1

dark layers correspond to documented organic layers interpreted as cultural strata map: Institute of Archaeological Sciences, University of Bern

In comparison, the middle part of the profile from metre 1-6 shows a heavily disrupted stratigraphy. The main features are two deep cracks, at metre $0-1$ and at metre 5.5-6. The cracks are filled with secondary surface material.
The sediment in layer 4 consists of a heterogeneous lake marl with an uneven structure and density. The layer has a lenticular shape, which indicates its secondary sedimentation. It seems that the root pit lay open for re-sedimentation of lake marl from the uplifted root plate. 
Underneath this secondary layer several sediments with heavy disruptions are situated. As can be observed in profile 2 (Fig. 4), this package slid or fell into the root pit. Inside the pit the package lay in a watery environment for the distinctive layered sedimentation at its tails to be formed. It is unclear whether the package still lies in its original orientation or whether it was flipped upside down by the violent uprooting of the tree. The reddish colour originating from heat (fire) in the lower parts of the clay package may indicate its having been flipped, as such patterns are typical of hearths and similar finds and usually appear on the upper surfaces.

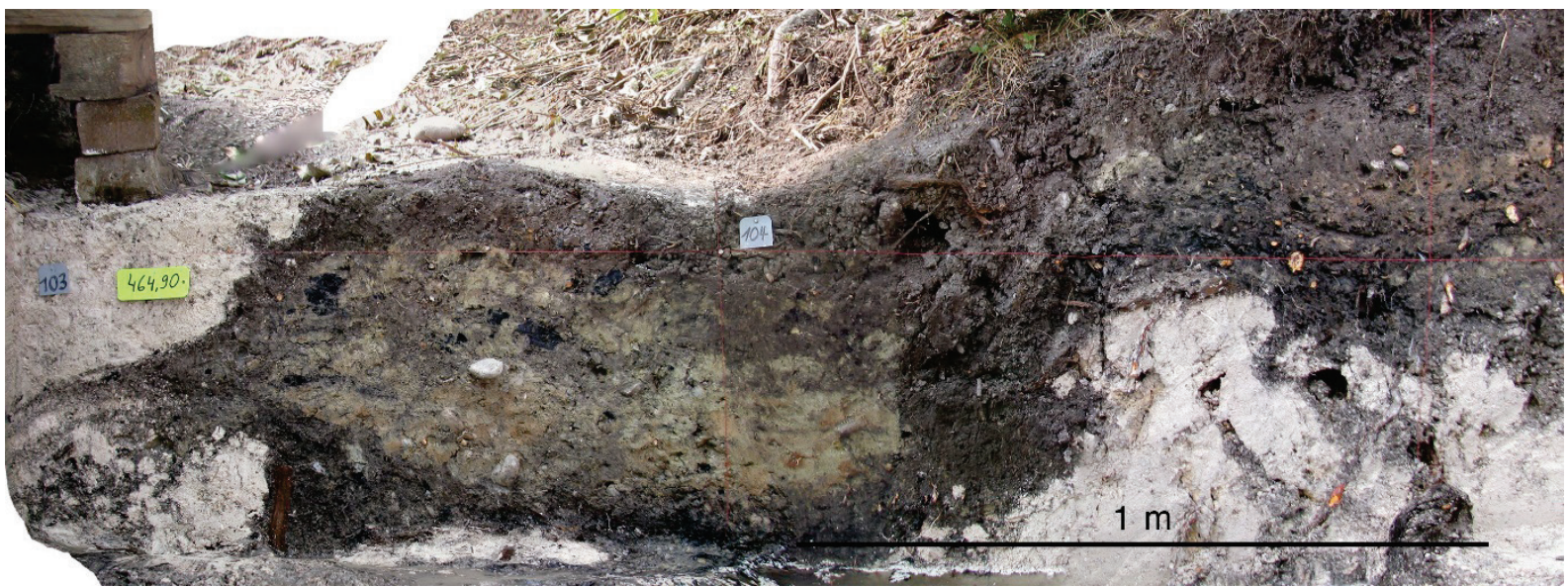

Fig. 4. Aeschi SO, Burgäschisee, Nord. Profile 2 of trench \#1 through the loamy package

it is visible how the package slid down into the root pit and remained in a watery environment for some time; orthomosaic reconstructed from photos

image: Institute of Archaeological Sciences, University of Bern, orthomosaic: M. Hostettler, Institute of Archaeological Sciences, University of Bern

Even though tree windthrows happen in different kinds of environments, this instance can be linked to the location on a former wetland. Langohr (1993) describes different factors determining the frequency of tree windthrows. Wet soils are more important as a risk factor than the actual force of the wind (Langohr 1993). Other important factors are reduced deep-rooting of trees, which results from "shallow soils", which includes soils with high water tables or other deeper soil horizons unsuitable for rooting as bedrock or other impenetrable soils like loam, undisturbed loess and others (Langohr 1993). Additionally, small forest stands are more sensitive to the impact of wind than are larger ones.

The area at the northern shore of Lake Burgäschi shows several risk factors for tree-windthrows: a) the former wetland and peat bog soil on the northern shore tends to soak massively with water and heavy rainfall can raise the water table considerably; b) the high water table prevents deep-rooting of trees growing in this area; c) the small forest at the northern shore covers an area of approximately $23,000 \mathrm{~m}^{2}$, including a short extension of less than $50 \mathrm{~m}$ wide along the shore, which is thus heavily exposed to wind.

Tree windthrows can considerably disturb the stratigraphic integrity of a site. In this case an area of about $30 \mathrm{~m}^{2}$ and a depth of more than $1 \mathrm{~m}$ has been disturbed. The resulting damage to the archaeological context can be described as follows. Masses of soil material and artefacts were translocated, creating new stratigraphic layers, mixing up different contexts, and maybe even inversing the stratigraphic sequence. This has caused severe problems for the chronological and cultural evaluation of the archaeological material. Tree windthrows and uprooting thus have a heavy impact on the preservation of a site and may have severe effects on its contextual coherence.

\section{Draining and decomposition}

During the three-year campaign of 2015-17 at the northern shore of Lake Burgäschi, ten trenches were opened and documented. The trenches yielded insights into the condition of the soil and the preservation of the archaeological remains. The archaeological layers are located at an altitude of some centimetres above $465 \mathrm{~m}$ a.s.l. and are thus above the permanent water table, which is at around $464.75 \mathrm{~m}$ a.s.l. This means that the archaeological layers are in a mostly dry condition and, at most, only partially and seasonally waterlogged. 
In most cases the archaeological layers were located directly underneath the humus. The covering layer was a narrow sediment grown through by the roots of the covering vegetation. It had a thickness of approximately 10-20 cm. Exceptions were: trench \#1, where the covering layer was equal to the first archaeological layer and contained archaeological remains; and trench \#8, where the archaeological layers were located at a depth of about one metre below the ground. Table 1 shows the thickness of the peat and the cultural layers as documented in the drillings of 1945. The peat and turf layer constituting the uppermost sediment had an average thickness of about $40 \mathrm{~cm}$, while the cultural layer has an average of about $20 \mathrm{~cm}$. The data were taken from the drillings in the same area where trenches \#4, \#6, and \#10 from 2015-17 are located (see Fig. 2, purple dots beside trenches \#4-10). The new documentation shows a maximum of $10 \mathrm{~cm}$ for the covering humus and a maximum of $7 \mathrm{~cm}$ for the cultural layer. Both layers have thus lost more than half of their depth.
This shrinking of the layers can be attributed to the draining of the soil and the decomposing of the original peat bog layers around the lake. The peat bog has since disappeared completely.

For Lake Burgäschi, no comparative studies or data are available to assess the ancient water table and bio-chemical conditions of the soil. To assess the preservation condition of the organic material, the observations from the earlier excavations were compared to the results from 201517. The early excavations were recorded using documentation standards far much lower than today's and reports are often very summary; nonetheless, they give insights into the categories of excavated objects and materials. The fragmentary nature of the available data only allows a presence/absence table (Table 2) of certain organicfind categories to be drawn up. Despite its limitations, the table offers an insight into the scale of loss of archaeological data.

Table 1

Thickness of peat layers as documented in drilling cores of 1945 in the area of new trenches \#4, \#6 and \#10, and measured data from 2015-17 in trenches \#6 and \#10

\begin{tabular}{|c|c|c|c|c|c|}
\hline \multirow{2}{*}{ Drilling \# } & \multicolumn{2}{|c|}{ Thickness after drilling cores 1945 } & \multicolumn{3}{|c|}{ Thickness after excavations 2015-17 } \\
\cline { 2 - 6 } & $\begin{array}{c}\text { Archaeological } \\
\text { layer in cm }\end{array}$ & $\begin{array}{c}\text { Peat thickness } \\
\text { in cm }\end{array}$ & Trench \# & $\begin{array}{c}\text { Archaeological layer } \\
\text { in cm, min, max }\end{array}$ & $\begin{array}{c}\text { Humus } \\
\text { in cm }\end{array}$ \\
\hline 1 & 28 & 35 & 10 & 3,16 & 10 \\
\hline 2 & 20 & 40 & 6 & & 10 \\
\hline 7 & 18 & 58 & & & \\
\hline 8 & 17 & 42 & & & \\
\hline 14 & 14 & 30 & & & \\
\hline 15 & 18 & 30 & & & \\
\hline 16 & 28 & 34 & & & \\
\hline 1 & 23 & 45 & & & \\
\hline 22 & 19.6 & 38.8 & & & 10 \\
\hline Average & & & & & \\
\hline
\end{tabular}

Table 2

Burgäschisee. Presence/absence table of different find categories of organic remains and artefacts

\begin{tabular}{|l|c|c|c|c|c|c|}
\hline & 1877 & 1902 & 1943 & 1946 & $1952-1957$ & $2015-2017$ \\
& Nord & Nord & Nord & Südwest & Süd & Nord \\
\hline Textiles, fibres & - & yes & - & yes & $?$ & - \\
\hline Botanic remains & yes & yes & - & yes & yes & - \\
\hline Wooden artefacts & yes & yes & - & yes & yes & - \\
\hline Organic constructive elements & - & yes & yes & - & yes & - \\
\hline Piles reach into cultural layer & yes & yes & yes & yes & yes & - \\
\hline Bone and antler & yes & yes & yes & yes & yes & yes \\
\hline
\end{tabular}

Nord 1877 (Keiser 1879a, b), Nord 1902 (Kasser 1903; Wiedmer-Stern 1904), Nord 1943 (Pinösch 1947, map 1943), Südwest 1946 (Wey 2012), Süd 1952-57 (Wey 2012), Nord 2015-17 (Hafner, Hostettler in prep.) 
To add additional time slices for comparison between the lowering of the lake level and the years 2015-17, the sites of Seeberg BE, Burgäschisee, Südwest and Süd have been added to the table. Seeberg BE, Burgäschisee, Südwest was excavated shortly after the lowering of the lake in 1946, and Seeberg BE, Burgäschisee, Süd was excavated in 1952-57. Both examples give insights into the preservation conditions a few years after the artificial lake lowering and the start of the draining process.

The first three excavations lack a systematic methodology. This can be ascribed either to the pioneering nature of the research $(1877,1902)$ or to the difficulties of the circumstances. In 1943, the observations were undertaken during the construction of the new outflow.

The table (Table 2) clearly shows how, until 1943, the preservation of the objects in Aeschi SO, Burgäschisee, Nord was in a generally good condition. The excavation of 1902 yielded all types of organic finds, indicating that preservation was still pristine at that time. In 1943 the excavation yielded less organic material, which may be due to the fact of being a rescue documentation. Thus, there was no possibility to search for small finds such as fibres or fragile wooden artefacts. However, the organic preservation was still good, as the documented piles reached into the cultural layer, and there was ample evidence of wooden construction elements.

In 1946, excavation took place in Aeschi SO, Burgäschisee, Ost and in Seeberg BE, Burgäschisee, Südwest. The organic preservation still had the same quality as that from before the lake level had been lowered. Not too much deterioration occurred in these first three years.

The excavation of Seeberg BE, Burgäschisee, Süd took place about ten years later, in 1957-58. It was one of the first large scientific excavations to apply cutting-edge technology and an interdisciplinary approach to the evaluation of results. The excavators applied a broad sampling strategy including sedimentological profiles for palynological research, and sampling of macro-plant and faunal remains for archaeobotany and archaeozoology. During the excavation, the first steps in applying dendrochronology and radiocarbon methodology to archaeological remains were also undertaken in a pioneering way.

It is unclear to what extent the deterioration had already started in 1957/58. There are reports of textiles and fibres having been excavated, though they were never studied or published. All other objects were found, excavated and analysed, and reports and studies published (Boessneck et al. 1963; Müller-Beck, Schweingruber 1965; Brunnacker et al. 1967; Bandi et al. 1973; Bleuer, Dubuis 1988; Müller-Beck 2005; Müller-Beck 2008; Wey 2012).

Although the overall preservation still seemed pristine, the archaeobotanical evaluation showed that deterioration had already started. As Villaret-von Rochow (1967) states, the macro-remains of seeds and other botanical remains showed a stratigraphic order concerning their preservation. In the deepest layers the seeds appeared to have been preserved in very good condition. In the second layer they had started to decompose and were in a brokenup and deteriorated state. The top layer no longer showed any traces of uncharred botanical remains.

About 60 years later the only organic material to be left are bones and antler. In 2015-17 there were no traces of fibres, no traces of uncarbonised seeds or other remains, and no wooden artefacts or construction elements, and the piles were preserved only under the permanent water table. The same conclusion was made by Brombacher in the evaluation of the macro remains from the excavations of 2015-17 (Brombacher in Hafner, Hostettler in prep.). The botanical specimens include only remains of species that have a very robust cellular basis, such as hazelnut shells. Using the fragility of these microscopic remains with the knowledge of the usual plant spectrum in well-preserved settlements, the preservation level of a sample can be assessed. Applying such a ranking to the specimens from the sites around lake Burgäschi, Brombacher underlines that the observed organic degradation is alarmingly advanced at Aeschi SO, Burgäschisee, Nord.

The draining of the lake and subsequent lowering of the water table at the site resulted in a heavy loss of organic material, as reflected both in the decrease in volume of organic soil and in the loss of organic archaeological artefacts. Additionally, the diminished volume and water saturation resulted in cracks and fissures in the ground, inviting small animals to inhabit the cavities. These processes can lead to the translocation of archaeological objects into lower layers, which constitutes a loss of contextual integrity. But the most important damage is the permanent loss of outstanding archaeological artefacts and ecofacts, which causes a serious loss of information for the understanding of the past.

\section{Discussion and results}

The case of Lake Burgäschi is not a singular instance. A history of peat exploitation, lake level lowering, draining of peat bog areas, a collapsed ecosystem and resulting eutrophication are typical 
for wetlands and small lakes in Switzerland and on a global level. However, quantification of the loss of archaeological information in wetlands is difficult.

"Monuments at Risk in England's Wetlands (MAREW)" was a research project into the changing nature of the archaeological resource in England's wetlands 1950-2000. The project was commissioned by English Heritage, and undertaken by the Centre for Wetland Research, University of Exeter. The project led to an estimate of the number of destructed wetland sites, and evaluated the main causes for the destructions. Between 1950 and 2000 the study estimates the partial loss of about 15,000 sites due to drainage or water abstraction (van de Noort et al. 2002). At the same time, there is a range of other causes affecting wetland sites, such as the conversion of the agriculture type, peat erosion and wastage, urban/industrial development and peat extraction, to name a few.

There are no studies in Switzerland focusing on the loss of wetland objects of heritage or archaeological sites, but the loss of wetlands as such has been recently estimated for the timeframe from 1850 to 2010 (Müller et al.2018). The study shows that, especially during the period between 1950 and 2010, most regions lost about $70 \%$ or more of their wetland area (Müller et al. 2018). This corresponds to the timeframe in which most of the archaeological information at Lake Burgäschi was endangered and lost. If we assume that in the total amount of wetlands a certain number of archaeological monuments was present, we must assume a similarly high $(\sim 70 \%)$ loss of archaeological objects as we do lost wetlands.

A particular problem concerning wetland sites is the immediate danger of heavy information loss in a short timeframe.

Similar examples to lake Burgäschi are the Neolithic sites at the lakes of Moossee and Lobsigen, both located in the Canton of Bern (Suter, Hafner 2005a, b; Hafner 2009; Hafner et al. 2012; Harb 2017; Heitz 2020). In both cases the organic materials have been heavily diminished in recent years, when compared to what was documented when the sites were discovered in the $19^{\text {th }}$ century. Brombacher (2020) states for the site of Seedorf BE, Lobsigensee most of the fragile organic remains have deteriorated. Only very robust plant remains as hazelnut remained in 2008, when parts of the site were excavated. Almost no wooden artefacts or construction remains were found at the site.

Only recently, investigations into the degradation of organic matter were carried out at the same site. Here, modern organic cotton and wood were buried in order to monitor their degradation over several years. The measurements allowed conclusions to be drawn regarding the processes and rates of degradation of organic material. A long-held suspicion was confirmed: organic material in archaeological layers and soils that are drying out and no longer saturated with water are destroyed within a few decades (Matile et al. 2020).

To monitor the Iron Age site in Biskupin (Poland), experiments on modern oak were conducted to assess the effects of deterioration of wood in waterlogged conditions. Recent results showed that the wood, which was buried for 10 years in waterlogged conditions and in peat, showed very little deterioration, mainly due to the loss of substances soluble by water. This confirms that in-situ conservation of archaeological wood needs stable waterlogged conditions to be successful (most recent: Babiński et al. 2019; Lucejko et al. 2020; Zborowska et al. 2020).

Another example of monitoring a waterlogged site is the Neolithic-Bronze Age settlement of Fiavé in the southern Alpine region of Trentino. This pile-dwelling site is included in the UNESCO Heritage List and interesting for the conservation of piles in a wetland environment. The main issue here is whether wooden posts visible to the public can still be shown in this way or whether they need to be protected by reburial (Dal Rì et al. 2012).

Wetland sites demand permanent monitoring and immediate action if changes to the water table, water saturation or soil chemistry are registered. If not, destruction typically happens unnoticed and is only discovered when newly excavated. An example where recent destruction was discovered during excavation is the Mesolithic site of Starr Carr, near Scarborough, North Yorkshire, on the east coast of England. The bog site was discovered and partially excavated in the 1940s and 1980s. The site yielded high amounts of organic artefacts and ecofacts. Several field drains in 2000 caused a drop in the water table, causing deterioration of the organic material to set in. Excavations between 2006 and 2010 were alarming and reported the demineralisation of bones, the flattening and crumbling of wood and the loss of palynological information (High et al. 2016). The deterioration at Starr Carr may be linked to two main impact factors. First, the sinking of the water table below the archaeological sediments and thus an end to the waterlogging of these sediments. Second, the contamination of the peat bog by sulphuric acid caused by the oxidation of sulphuric sediments below the peat bog after the lowering of the water table (High et al. 2016).

The entanglement of wetlands in their surrounding landscape calls not only for the monitoring 
of specific sites (e.g. Chapman, Cheetham 2002; Wagstaff et al. 2016), but for a conservation strategy for the entire entangled environment (as demanded by, for instance, Brunning 2013 or GillRobinson 2010, or for the specific context of the UNESCO World heritage see Corboud, Gowen 2016). The main goal of such an approach must be the protection and conservation of sites and artefacts in-situ, as shown by the examples above. This strategy saves public money because in-situ conservation is far less expensive than excavations, analysis and long-term storage of the documented and retrieved objects. Furthermore, this approach gives the possibility of future analysis. In-situ conservation is not only in line with the (revised) Convention for the Protection of the Archaeological Heritage of Europe of 1992, but is also practised in most cultural management agencies in Switzerland and Europe (Hafner 2008, 2012). A series of conferences concerned with in-situ conservation of archaeological sites started soon after, in 1996, in London and has since repeatedly been organised, with the last conference having taken place in 2015 in Kreuzlingen, Switzerland (Leuzinger et al. 2016).

However, for artificially drained wetlands such as lake Burgäschi, in-situ conservation becomes difficult. To achieve this goal, a restitution of the peat bog ecosystem and a rewetting would be needed. This again has a major impact on the surroundings and has to be solved politically. In 1989 a rejected proposal (Weber 1989) suggested restoring the peat bog around Burgäschi by lifting the lake level by one metre. The proposal had only focused on the natural ecosystem and did not mention the archaeological heritage; nevertheless; it could have had a considerable impact on its preservation.

It is not always clear whether restitution measures are able to stop the deterioration of archaeological information. If rewetting is not carefully monitored and assessed, the destruction of a site and the artefacts can proceed (for instance, the roots of several wetland plants can destroy archaeological artefacts, see e.g. Tjelldén et al. 2015). Additionally, political and legal boundaries can make such a strategic and comprehensive approach very costly and difficult.

The peat bog and lake ecosystem of the Federseemoor in Southern Germany may act as an example of a particularly successful heritage management strategy. With collaboration between environmentalists and public institutions (such as the State Monuments Office) they initiated not only a permanent research facility for the interdisciplinary research of the wetland sites: a natural and cultural reserve was also created, and the initiative succeeded in rewetting much of the former peat bog area. This procedure enabled a natural restitution of the ecosystem together with in-situ preservation for the archaeological and environmental archives (for an overview, see Schlichtherle 2016).

If such an approach is not possible, or if the framework for in-situ preservation cannot be installed to the required extent, and if the sites are at risk of being "abandoned in situ', with their future survival a matter of unknown probability" (Brunning 2013), immediate excavation seems to be the best measure at hand to save the remaining archaeological information.

\section{Conclusion}

Summing up, the Neolithic site of Aeschi SO, Burgäschisee, Nord was affected in several different ways after the lowering of the lake level in 1943. First, the soil containing the archaeological layers became permanently dry when the water table fell. Second, the site was overgrown by a small forest, thus putting it at risk of tree-windthrows and destruction by rooting within the archaeological layers. And, third, the draining of the formerly waterlogged anoxic organic layers resulted in the immediate onset of organic deterioration. In the first ten years after drainage, especially fragile organic artefacts (textiles, fibres, fragile botanical remains) already began to disappear. Sixty years later, and seven decades after the lake level lowering, most organic remains had completely decayed. The level of retrievable information for archaeological and palaeoenvironmental studies has considerably decreased in a short amount of time, compared to the thousands of years of preservation. Obviously, this loss is permanent - even if the habitat can be restored and flora and fauna are protected (for examples see Gill-Robinson 2010).

The sites of Aeschi SO, Burgäschisee, Ost, Seeberg BE, Burgäschisee, Südwest and Seeberg BE, Burgäschisee, Süd were excavated shortly after the lake level lowering. Thanks to these quick and decisive actions, at least part of the endangered evidence was successfully documented. This is especially true for Seeberg BE, Burgäschisee, Süd, where the introduction of both radiocarbon dating and dendrochronology, as well as a fully interdisciplinary approach, marked the beginning of a new state of the art for wetland archaeological research in Switzerland.

At Aeschi SO, Burgäschisee, Nord the in-situ preserved remains are still in immediate danger of 
total loss if the described effects on the archaeological layer continue to advance. A rewetting of the area, however, seems no longer justifiable from a purely archaeological point of view, because there are only comparably few remains left. Additionally, deterioration is in an advanced state. An excavation would give the possibility to at least rescue the remaining archaeological data and seems to be the best measure in this case.

\section{References}

Babiński L., Fabisiak E., Zborowska M., Michalska D., Prądzyński W. 2019. Changes in oak wood buried in waterlogged peat: shrinkage as a complementary indicator of the wood degradation rate. European Journal of Wood and Wood Products 77: 691-703. https://doi.org/10.1007/s00107019-01420-z

Bandi H.-G., Sangmeister E., Spycher H., Strahm C., Zimmermann K. 1973. Seeberg, Burgäschisee Süd. 6: Steingeräte und Kupferfunde. Acta Bernensia II. Stämpfli Verlag, Bern.

Bleuer E., Dubuis B. 1988. Seeberg, Burgäschisee-Süd. 7: Die Knochen- und Geweihartefakte und die ergänzte Keramik. Acta Bernensia II, Stämpfli Verlag, Bern.

Boessneck J., Jéquier J.-P., Stampfli H.R. 1963. Seeberg, Burgäschisee-Süd. 3: Die Tierreste. Acta Bernensia II, Stämpfli Verlag, Bern.

Brombacher C. 2020. Botanische Makroreste, in Heitz, C. 2020. Abseits der grossen Seen. Archäologie und Erhaltung der neolithischen Unesco-Welterbe-Fundstelle Seedorf. Lobsigensee, Bern.

Brunnacker K., Heim R., Huber R., Klötzli E. (eds) 1967. Seeberg, Burgäschisee-Süd. 4: Chronologie und Umwelt. Acta Bernensia II, Stämpfli Verlag, Bern.

Brunning R. 2013. Archaeological Strategies for Terrestrial Wetland Landscapes. In: F. Menotti, A. O'Sullivan (eds) The Oxford Handbook of Wetland Archaeology. Oxford University Press, Oxford.

Chapman H.P., Cheetham J.L. 2002. Monitoring and Modelling Saturation as a Proxy Indicator for in situ Preservation in Wetlands - a GIS-based Approach. Journal of Archaeological Science 29: 277-289.

Corboud P., Gowen M. 2016. Protection of the World Heritage against archaeological research: the case of the prehistoric pile dwellings around the Alps registered at UNESCO. Jahrbuch Archäologie Schweiz 99: 157-164.

Dal Rì C., Fruet S., Bellintani P., Pisu N., Macchioni N., Pizzo B., Capretti C. 2012. Preserving Archaeological Remains In Situ: Three Case Studies in Trentino, Italy. Conservation and Management of Archaeological Sites 14,1-4: 239-248, DOI: 10.1179/1350503312Z.00000000020

Ebersbach R., Kleinmann A., Maier U., Mainberger M., Merkt J., Million S., Nedle O., Schlichtherle H., Stephan E., Vogt R., Wick L. 2017. Das BELAVI-Projekt erschliesst eine neue Feuchtboden-Fundlandschaft des Neolithikums im Westallgäu. Archäologische Ausgrabungen in $\mathrm{Ba}$ den-Württemberg 2016: 22-25.

Gill-Robinson H. 2010. Managing Wetland Archaeology: Environmental Degradation at Wetland Archaeological Sites. In: F.P. McManamon, A. Stout, J.A. Barnes (eds) Managing Archaeological Resources. Global Context, National Programs, Local Actions, One World Archaeology. Walnut Creek: 233-240.

Guthruf J., Guthruf-Seiler K., Zeh M. 1999. Kleinseen im Kanton Bern. Petits plans d'eau du canton de Berne. Bern.

Hafner A. 2008. In Situ Preservation of submerged prehistoric settlements in Lakes of the Alpine Region. Anti-Erosion measures at sites in Lake Bienne, Switzerland. In: H. Kars, R.M. Van Heeringen (eds) Preserving archaeological remains in situ. Proceedings of the 3rd conference, 79 December 2006. Geoarchaeological and Bioarchaeological Studies, vol. 10. Amsterdam: Vrije Universiteit Amsterdam: 245-251.

Hafner A. 2009. Die schleichende Zerstörung von aussergewöhnlichem Kulturgut: Archäologische Ausgrabungen in Seedorf, Lobsigensee. Seebutz. Heimatbuch des Seelandes und Murtenbiets 2009: 37-41.

Hafner A. 2012. Sutz-Lattrigen, Lake Biel, Switzerland. Twenty years of rescue excavations and in situ conservation. In: J. Henderson (ed.) Beyond Boundaries. Proceedings of the 3rd International Congress on Underwater Archaeology. Kolloquien zur Vor- und Frühgeschichte: Vol. 17. Bonn: 337-344.

Hafner A., Harb P., Amstutz M., Francuz J., Moll-Dau F. 2012. Moosseedorf, Moossee Oststation, Strandbad. Strandbadneubau, Pfahlbauten und das älteste Boot der Schweiz. Archäologie Bern/Archéologie bernoise 2012: 71-77.

Hafner A., Rey F., Laabs L., Bolliger M., Brombacher C., Francuz J., Gobet E., Häberle S., Hostettler M., Rentzel P., Schäfer M., Schibler J., Wey O., Tinner W. 2020. Archaeological and palaeoecological investigations at Burgäschisee. In: A. Hafner, E. Dolbunova, A. Mazurkevich, E. Pranckenaite, M. Hinz (eds) Settling Waterscapes in Europe. The Archaeology of Neolithic and Bronze Age Pile Dwellings. Open Series in Prehistoric Archaeology OSPA 1, Heidelberg: 169200.

Hafner A., Hostettler M. (eds), in prep. Beyond Lake Villages. Studien zu Landnutzung \& Besiedlungsgeschichte im Neolithikum der Schweiz. 
Harb C. 2017. Moosseedorf, Moossee. Ein Überblick über 160 Jahre Pfahlbauforschung. Hefte zur Archäologie im Kanton Bern 2. Bern.

Heitz C. 2020. Abseits der grossen Seen. Archäologie und Erhaltung der neolithischen Unesco-Welterbe-Fundstelle Seedorf, Lobsigensee, Hefte zur Archäologie im Kanton Bern 7, Bern.

High K., Milner N., Panter I., Demarchi B., Penkman K.E.H. 2016. Lessons from Star Carr on the vulnerability of organic archaeological remains to environmental change. Proceedings of the $\mathrm{Na}$ tional Academy of Sciences of the United States of America 113, 12957. https://doi.org/10.1073/ pnas. 1609222113

Kasser H. 1903. Archäologische Abteilung, in: Jahresbericht Des Historischen Museums in Bern pro 1902. Bern.

Keiser J. 1879a. Antiquarische Notizen aus der Umgebung von Burgdorf. Jahresbericht über das Gymnasium in Burgdorf am Schlusse des Schuljahres 1878/79. Burgdorf.

Keiser J. 1879b. Der Pfahlbau am Burgäschi-See (Kanton Bern). Pfahlbauten. Achter Bericht, Mitteilungen der Antiquarischen Gesellschaft in Zürich 20: 25-26.

Kowarik K., Klammer J., Seidl da Fonseca H., Maurer J., Taylor T. 2020. From lakeshore to hilltop. In: A. Hafner, E. Dolbunova, A. Mazurkevich, E. Pranckenaite, M. Hinz (eds) Settling Waterscapes in Europe. The Archaeology of Neolithic and Bronze Age Pile Dwellings. Open Series in Prehistoric Archaeology OSPA 1, Heidelberg: 229246.

Langohr R. 1993. Types of Tree Windthrow, their Impact on the Environment and their Importance for the Understanding of Archaeological Excavation Data. Helinium 33: 36-49.

Leuzinger U., Sidell J., Williams T. 2016. The 5th International Conference on Preserving Archaeological Remains In Situ (PARIS5): 12-17 April 2015, Kreuzlingen (Switzerland), Conservation and Management of Archaeological Sites, 18:13, 1-7, DOI: 10.1080/13505033.2016.1182748

Lucejko J.J., Tamburini D., Zborowska M., Babiński L., Modugno F., Colombini M.P. 2020. Oak wood degradation processes induced by the burial environment in the archaeological site of Biskupin (Poland). Heritage Science 8, 44. https://doi. org/10.1186/s40494-020-00390-3

Mainberger M., Baum T., Ebersbach R., Gleich P., Hesse R., Kleinmann A., Maier U., Merkt J., Million S., Nelle O., Stepha E., Schlichtherle H., Vogt R., Wick L. 2020. New perspectives on archaeological landscapes in the south-western German alpine foreland. In: A. Hafner, E. Dolbunova, A. Mazurkevich, E. Pranckenaite, M. Hinz (eds) Settling Waterscapes in Europe. The Archaeology of Neolithic and Bronze Age Pile Dwellings. Open Series in Prehistoric Archaeology OSPA 1, Heidelberg: 201-228.
Matile L., Haab R., Krebs R. 2020. Monitoring des Abbaus und der hydrologischen Verhältnisse des dränierten Niedermoors. In: C. Heitz (ed.) Abseits der grossen Seen. Archäologie und Erhaltung der neolithischen Unesco-Welterbe-Fundstelle Seedorf, Lobsigensee: 307-316.

Müller M., Gimmi U., Loran C. 2018. 5. Wie hat sich die Fläche der Feuchtgebiet in der Schweiz entwickelt? In: M. Stuber, M Bürgi (eds) Vom "Eroberten Land" Zum Renaturierungsprojekt. Geschichten Der Feuchtgebiete in Der Schweiz, Bristol-Schriftenreihe. Bern: 155-178.

Müller-Beck H. 2005. Seeberg, Burgäschisee-Süd. 1: Topographie und Stratigraphie. Acta Bernensia II, Stämpfli Verlag, Bern.

Müller-Beck H. 2008. Seeberg, Burgäschisee-Süd. 2: Bauten und Siedlungsgeschichte mit einem Beitrag von O. Wey. Acta Bernensia II, Stämpfli Verlag, Bern.

Pinösch S. 1947. Der Pfahlbau Burgäschisee-Ost. Jahrbuch für Solothurnische Geschichte 20: 197.

Rey F., Gobet E., van Leeuwen J.F.N., Gilli A., van Raden U.J., Hafner A., Wey O., Rhiner J., Schmocker D., Zünd J., Tinner W. 2017. Vegetational and agricultural dynamics at Burgäschisee (Swiss Plateau) recorded for 18,700 years by multi-proxy evidence from partly varved sediments. Veget Hist Archaeobot 26: 571-586. https://doi.org/10.1007/s00334-017-0635-x

Schlichtherle H. 2016. Pfahlbauten in Südwestdeutschland. Archäologische Anfänge und neue Wege der Forschung und Denkmalpflege. Denkmalpflege in Baden-Württemberg 2016: 3-10.

Suter P.J., Hafner A. 2005a. Moosseedorf, Moossee Ost. Sondierung 1999 und Dokumentation 2001: jungneolithische Ufersiedlung. Archäologie im Kanton Bern 6A: 29-32.

Suter P.J., Hafner A. 2005b. Seedorf, Lobsigensee. Fundrückführung 1997: jungneolithische Ufersiedlung. Archäologie im Kanton Bern 6A: 37-41.

Tjelldén A.K.E., Kristiansen S.M., Matthiesen H., Pedersen O. 2015. Impact of Roots and Rhizomes on Wetland Archaeology: A Review. Conservation and Management of Archaeological Sites 17,4: 370-391, DOI:10.1080/13505033.2016. 1175909

Van de Noort R., Fletcher W., Thomas G., Carstairs I., Patrick D. 2002. Monuments at Risk in England's Wetlands (Final Report). University of Exeter.

Villaret-von Rochow M. 1967. Frucht- und Samenreste aus der neolithischen Station Seeberg. In: K. Brunnacker, R. Heim, R. Huber, E. Klötzli (eds) Seeberg, Burgäschisee-Süd. 4: Chronologie und Umwelt. Acta Bernensia II, Stämpfli Verlag, Bern: 21-64.

Wagstaff S., Cheetham J., Davis A., Williams J., Outram Z., Priddy D., Chapman H. 2016. Hydrogeological Modelling of Water-Level Changes in an Area 
of Archaeological Significance: A Case Study from Flag Fen. Cambridgeshire, UK. Conservation and Management of Archaeological Sites 18: 156-169. https://doi.org/10.1080/13505033.2016. 1182753

Weber D. 1989. Natur- und Landschaftsschutzkonzept Burgäschisee, Chlepfibeerimoos und Umgebung.

Wey O. 2012. Die Cortaillod-Kultur am Burgäschisee. Materialvorlage und Synthese zu den neolithischen Fundkomplexen von BurgäschiseeOst, -Südwest, -Süd, und -Nord. Mit einem Beitrag von Antoinette Rast-Eicher und Susi UlrichBochsler. Acta Bernensia XIII. Stämpfli, Bern.
Wiedmer-Stern J. 1904. Archäologisches aus dem Oberaargau. Archiv des Historischen Vereins des Kantons Bern 17: 302-512.

Zborowska M., Babiński L., Czaczyk K., Pawlicka-Kaczorowska J., Prądzyński W. 2020. Evaluation of the rate of wood degradation at the Iron Age archaeological site in Biskupin (Poland). Archaeometry 62,1: 141-156.

Zeh M. 2007. 30 Jahre Tiefenwasserableitung. Wie geht es dem Burgäschisee heute? Bern. 